\section{Performance of Micropropagated 'Queen Elizabeth' Rose following Mechanically Induced Stress}

\author{
Martine Korban and Danielle J. Donnelly \\ Plant Science Department, Macdonald Campus of McGill University, 21)111 \\ Lakeshore Road, Ste Anne-de-Bellevue, PQ H9X 3V9, Canada
}

Additional index words. Rosa $\times$ hybrida, ex vitro acclimatization, in vitro hardening, shaking stress, micropropagation

Abstract. Mechanically induced stress (shaking stress) applied during shoot multiplication (Stage II) or rooting (Stage III) of micropropagated 'Queen Elizabeth' rose was evaluated to determine its effects on in vitro hardening. Shaking during Stage II did not alter the growth responses of the shoots before transfer to Stage III. Shaking during Stage III, at 150 rpm for 15 min daily for 2 weeks, only caused a reduction in leaf dry weights before transfer to soil. Automated shaking stress during Stages II or III did not apparently promote hardening of cultured plants or improve their ex vitro performance.
The commercial production of micropropagated plants is often limited by poor survival when shoots or plantlets are transferred to greenhouse or field conditions. The in vitro environmental conditions combine to form a unique culture-induced phenotype (CIP) that affects ex vitro survival and performance of micropropagated plants. Various strategies for in vitro hardening have been used to modify the CIP toward improved storage capability, water relations, and/or photosynthetic competence (Donnelly and Tisdall, 1993).

Mechanically induced stress (MIS) occurs as a natural consequence of environmental conditions as aerial plant parts are moved by wind, rain, irrigation, animals, or machinery. Generally applied in the laboratory or greenhouse by shaking, brushing, or vibrating with air or water, MIS results in hardy, more stressresistant vegetable transplants (Biddington, 1985). One component of the CIP of micropropagated plants, which contributes to their fragility, is the lack of mechanical support tissue-less cell wall deposition and reduced collenchyma and sclerenchyma formation. This may result from the lack of air turbulence in stationary cultures (Donnelly et al., 1985).

The objective of these experiments was to determine whether MIS (shaking) treatment applied to in vitro shoots and plantlets promotes hardening of 'Queen Elizabeth' rose (Rosa sp.) before and/or after ex vitro acclimatization.

Received for publication 21 Jan, 1993. Accepted for publication 13 Aug. 1993. M.K. was financially supported by a postgraduate scholarship from the Natural Sciences and Engineering Research Council of Canada (NSERC). Partial financial support from NSERC (Grant AA2236) to D.D. is gratefully acknowledged. The cost of publishing this paper was defrayed in part by the payment of page charges. Under postal regulations, this paper therefore must be hereby marked advertisement solely to indicate this fact.
Mix Bx (Les Tourbières, Que., Canada) amended with dolomitic limestone (10 $\mathrm{g} \cdot$ liter $\left.^{-1}\right)$ and a granular, slow-release fertilizer, 14N-6P-11.6K (Osmocote; 6 g.liter ${ }^{-1}$ ). Flats were kept in a growth chamber at $25 \pm 1 \mathrm{C}$ with $125 \mu \mathrm{mol} \cdot \mathrm{m}^{-2} \cdot \mathrm{s}^{-1}$ cool-white fluorescent lights and a 16-h photoperiod for 5 weeks.

Treatments were applied to 1) 24 single shoots shaken daily for 4 weeks during Stage II growth, followed by Stage III culture (2 weeks) and ex vitro acclimatization (5 weeks); and 2) 24 axillary shoots shaken daily for 2 weeks during Stage III growth followed by ex vitro acclimatization (5 weeks). Control plants (24 shoots or plantlets for each set of treatments applied at Stages II and III) were not shaken. Culture tubes ( 24 tubes per treatment, at each stage) were held in racks arranged in a completely randomized design on the shelves of the culture room. Each morning (0900$1100 \mathrm{HR}$ ), racks were shaken at $150 \mathrm{rpm}$ for 15 or $30 \mathrm{~min}$ or at $200 \mathrm{rpm}$ for 15 or $30 \mathrm{~min}$ on an oscillatory orbit shaker frame (LabLine, model 3520; Canlab, Que., Canada).

Four plants from each treatment were used to measure shoot fresh and dry weights and stem diameters and lengths at the end of Stages II and III. At the end of Stage III and after ex vitro acclimatization for 5 weeks, the numbers of roots and leaves was determined along with fresh and dry weights of plant components. Dry weights were obtained following ovendrying of the samples at $60 \mathrm{C}$ for 3 days. The jected to analysis of variance (General Linear Models Procedure; PC-SAS). Mean separation of treatments was with Duncan's new multiple range test at $P \leq 0.05$.

\section{Results and Discussion} pH 5.8 with $1 \mathrm{~N} \mathrm{NaOH}$, dispensed into $25 \times$ $125-\mathrm{mm}$ culture tubes ( $10 \mathrm{ml} /$ tube), and autoclave at $121 \mathrm{C}, 103 \mathrm{KPa}$ for $20 \mathrm{~min}$.

Cultures were incubated in a walk-in culture room set at $25 \pm 1 \mathrm{C}$ with a 16 -h photoperiod under cool-white fluorescent lamps (40 W) providing a photosynthetic photon flux of $56 \mu \mathrm{mol} \cdot \mathrm{m}^{-2} \cdot \mathrm{s}^{-1}$ at culture level. After 4 weeks in the shoot multiplication medium (Stage II), axillary shoots ( 2 to $3 \mathrm{~cm}$ long) were subculture to a rooting medium (Stage III) with $5 \mu \mathrm{M}$ indolebutanoic acid replacing the cytokinin. Two weeks later, rooted shoots (plantlets) were transplanted into plastic-covered, 48cell $\left(80 \mathrm{~cm}^{3}\right)$ germination flats containing Proexperiment was repeated once. Data were subbenzyladenine. The media were adjusted to
There were no changes in in vitro shoot fresh and dry weights or stem lengths of rose shoots or plantlets shaken during Stages II and III compared with undisturbed control plants (data not shown). Leaf and root fresh weights and root dry weights of plantlets shaken during Stage III were not altered, but leaf dry weights were significantlyreducedwhen plantlets were shaken at $150 \mathrm{rpm}$ for $15 \mathrm{~min}$ and at $200 \mathrm{rpm}$ for $30 \mathrm{~min}$ compared with control plantlets (Table 1). Shaking stress was not effective in inhibitingshootandplantlet growth of in vitro 'Queen Elizabeth' rose. These results contradict reports of reduced shoot fresh and dry weights and inhibited stem and root
Table 1. The effect of shaking 'Queen Elizabeth' rose plantlets for 2 weeks during Stage III at 150 or 200 rpm for 15 or $30 \mathrm{~min}$ on leaf and root fresh and dry weights before ex vitro acclimatization.

\begin{tabular}{lcccccc}
\hline \multicolumn{2}{c}{ Shaking } & & \multicolumn{2}{c}{ Leaf } & & \multicolumn{2}{c}{ Root } \\
\cline { 5 - 7 } $\begin{array}{l}\text { Speed } \\
(\mathrm{rpm})\end{array}$ & $\begin{array}{c}\text { Duration } \\
(\mathrm{min})\end{array}$ & & $\begin{array}{c}\text { Fresh wt } \\
(\mathrm{g})\end{array}$ & $\begin{array}{c}\text { Dry wt } \\
(\mathrm{g})\end{array}$ & $\begin{array}{c}\text { Fresh wt } \\
(\mathrm{g})\end{array}$ & $\begin{array}{c}\text { Dry wt } \\
(\mathrm{g})\end{array}$ \\
\hline 0 & 0 & 0.16 & $0.034 \mathrm{a}$ & 0.075 & 0.006 \\
150 & 15 & 0.10 & $0.020 \mathrm{~b}$ & 0.063 & 0.006 \\
& 30 & 0.12 & $0.027 \mathrm{ab}$ & 0.046 & 0.005 \\
200 & 15 & 0.12 & $0.029 \mathrm{ab}$ & 0.048 & 0.006 \\
& 30 & & 0.09 & $0.017 \mathrm{~b}$ & 0.053 & 0.004 \\
Significance & & NS & $*$ & NS & Ns \\
\hline
\end{tabular}

Ns, "Nonsignificant or significant at $P \leq 0.05$, respectively. Mean separation within columns by least significance difference. 
elongation in seedlings of many MIS-treated herbaceous, greenhouse-grown plant species (Biddington and Dearman, 1985; Jones and Mitchell, 1992; Latimer, 1990). Although the shaking speeds and durations selected caused obvious shoot flexure inside the culture tubes, the physical stress may have been insufficient for a woody species like rose to respond substantially.

Plants exposed to MIS in vitro during Stage III showed variability in some growth responses (shoot fresh and dry weight, root and stem length) after 5 weeks of acclimatization (data not shown). However, these changes were probably not attributable to the shaking stress, since resumption of normal growth after MIS treatment was reported for most plant species (Biddington and Dearman, 1985; Latimer, 1990; Marler and Zozor, 1992).

Growth inhibition following MIS may result from altered leaf microclimate and gas exchange that lead to increased transpiration rates followed by reduced water potentials (Grace and Thompson, 1973). Shaking treatments probably disturbed the air inside the culture tubes but may not have affected the transpiration rates of plants growing under saturated relative humidity in vitro, or significantly affected the gas exchange between the closed tubes and the outside air. Plant response to MIS may have been affected by ambient temperatures and light levels in the culture room and growth chamber (Latimer, 1991; Latimer et al., 1986). Apparently, in the mixotrophic tissue-cultured plants, assimilates are preferentially translocated to newly developing tissues at the expense of additional cellwall deposition, and this is not affected by MIS.

\section{Literature Cited}

Biddington,N.L.1985.Theimportance of mechanically induced stress and its relevance to growth regulatorresearch.PlantGrowthRegulat.4:5-8.

Biddington, N.L. and A.S. Dearman. 1985. The effect of mechanically induced stress on the growth of cauliflower, lettuce and celery seedlings. Ann. Bet. 55:109-119.

Donnelly, D.J. and L. Tisdall, 1993. The cultureinduced phenotype. In: M,R. Ahuja (cd.). Micropropagation of woody plants. Kluwer Academic Publishers, The Netherlands.
Donnelly, D.J., W.E. Vidaver, and K.Y. Lee. 1985. The anatomy of tissue cultured red raspberry prior to and after transfer to soil. Plant Cell Tissue Organ Cult. 4:43-50.

Grace, J. and J.R. Thompson. 1973. The aftereffect of wind on the photosynthesis and transpiration of Festuca arundinacea. Physiol.Plant.28:54 1547.

Jones, R.S. arid C.A. Mitchell. 1992. Effects of physical agitation of greenhouse-grown soybean. Crop Sci. 32:404408.

Latimer, J.G. 1990. Drought or mechanical stress affects broccoli transplant growth and establishment but not yield. HortScience 25: 1233-1 235.

Latimer, J.G. 1991. Mechanical conditioning for control of growth and quality of vegetable transplants. HortScience 26:14561461.

Latimer, J. G., T. Pappas, and C.A. Mitchell. 1986. Growth responses of eggplant and soybean seedlings to mechanical stress in greenhouse and outdoor environments. J. Amer. Soc. Hort. Sci. 11:694698

Marler,T.E. and Y. Zozor.1992.Carambola growth and leaf gas exchange responses to seismic or wind stress. HortScience 27:9 13-9 15.

Murashige, T. and F. Skoog. 1962. A revised medium for rapid growth and bioassays with tobacco tissue cultures. Physiol. Plant. 15:473497 